\title{
Are The Home Prices Really Affected By The Quality Of The Public Schools: A Policy Analytical Perspective?
}

Gbolahan S. Osho, (Email: gosho@pvamu.edu), Prairie View A\&M University

Javier R. Castillo, Albert-Garaudy and Associates, Inc.

Joann J. Raphael, American InterContinental University

\begin{abstract}
It is a common belief in the Houston Area the better the School District where your home is located the higher the price that you may charge for your home. This study analyzes the relationship between the median home price and the Ranking of the School District where the home is located. This study also intends to analyze the average annual home price increases and the ranking of the schools. The hypothesis that the study intends to analyze is that the better the Schools the Higher the appreciation observed for the homes in the area.
\end{abstract}

\section{INTRODUCTION}

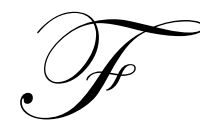

or most of the people in the US our home is the most important investment that we have. Is the place where we usually invest an important proportion of our income over the years? The home price trends is a matter of interest of not only for homeowners but for parents, economists, investors, policy makers, etc. "Households around the world have far more of their wealth tied up in property than in shares. American households' shareholdings briefly surpassed the value of their houses in the late 1990s. Now they have about $\$ 11$ trillion-worth of shares (held directly or in mutual funds), compared with almost $\$ 14$ trillion in housing." (18). The real state industry has expanded remarkably during the last decades, making real estate investment one of the most attractive ones and it seems that this trend of growth could be maintained during the following decades. Most of the public information regarding real state in Texas leads consumers to believe that the subdivisions with better public schools are the ones that ensure higher appreciation and therefore the better investment. It's a common belief that even though some areas may have higher property taxes the return on the investment of the home is better because in the long run the valuation of the home will ensure a better investment when compared with a subdivision without good public school.

Most of the world, however, has been enjoying a boom in house prices over the past few years, with prices rising at their fastest rate in real terms since the late 1980s in nine of our 13 countries. The largest real increases were in Madrid (15\%) and Sydney (13\%). Prices in London and New York wobbled during the fourth quarter of last year in the wake of September 11th, but are now rising again. Our overall global index gained a more modest 3\% in real terms last year, thanks to another fall in prices in Germany and Japan.

\section{THE REAL ESTATE INDUSTRY}

Several challenges that negatively affected some industries did not create as much harm as they did in other industries. While the information technology industry and the oil and gas industry were seriously affected by the stock market instability and the economic recession, the home real estate industry has enjoyed the economic stimulus implemented by the White House and the Federal Reserve. The recent tax cuts from the White House's fiscal policy pushed thousands of consumers to invest in their homes or were motivated to buy a home. Furthermore the reductions in the discount rates from the Federal Reserve's monetary policy caused many of consumers to visit the home improvement and hardware retailers to procure their goods and services. In the same way that the fiscal 
and monetary stimulus is required during recession times to drive consumers to the doors of real estate companies looking for more homes, the additional money supply during the economic expansion seems to invite the consumers to spend in the home improvement centers and hardware retailers. The three basic measures of macroeconomic performance are highly related to this industry: The Output (real GDP) growth, the unemployment rate and the inflation has been affecting the retail industry as we illustrate below. Due to the low output growth (GDP) rate observed during 2001 and 2002 and the generalized concerns on the economy; the Federal Reserve System and the White House have taken decisions that have helped the home improvement and hardware retail industry. The Federal Reserve and the White House have increased the money supply shifting the aggregate demand to the right. The Federal Reserve has decreased the required reserve ratio increasing the money supply and decreasing the mortgages rates. With lower mortgages rates, the aggregate demand for home improvement and hardware products shifted to the right, bringing excellent benefits to this industry. The White House has decreased the taxes, also increasing the money supply and shifting the aggregate demand for home improvement and hardware products shifted to the right.

The high unemployment rate has caused many Americans to reduce the investments in homes shifting the aggregate demand to the left. The low inflation rate observed in the last two years has also been of benefit for the real estate industry. With the decisions taken by the Federal Reserve and the White House discussed above, the net effect for the real estate industry seems to be positive as the latest economic indicators are showing a higher consumer confidence and higher revenues for the firms in this industry.

\section{THE HOME PRICES TRENDS}

As illustrated in the Figure 1.0, the house price index for USA has been positive for the period between Q3 1996 and Q2 2006. In the case of Houston Texas the house price index has been positive most of the time with the exception of the period between Q3 1996 and Q3 1999 and a brief period, 2006.

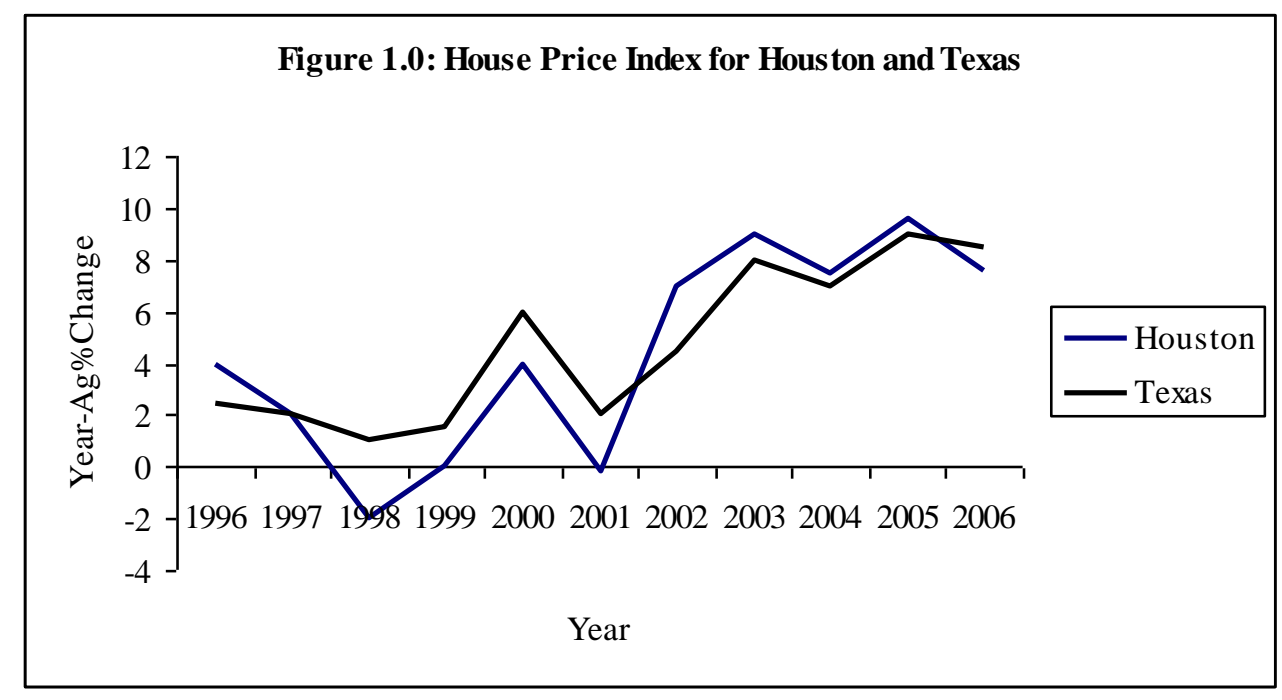

Table 1: The home appreciation in Houston compared with Texas and US

\begin{tabular}{cccc}
\hline Home appreciation & Houston, TX & TX & USA \\
\hline 1 Year & 0.071 & 0.074 & 0.086 \\
3 Years & 0.078 & 0.069 & 0.074 \\
5 Years & 0.063 & 0.054 & 0.061 \\
10 Years & 0.039 & 0.04 & 0.043 \\
\hline
\end{tabular}


Table 2.0 illustrates the General Home Appreciation for the sixty largest US markets by Population, based in average annual rates of the House Price index. This table also illustrates how the appreciation percentage changes depending on the period to be analyzed. In the case of Atlanta GA the appreciation for one year period is higher than the appreciation for a 10 year period. For this Sample the average annual rate for the 60 largest US markets by population was observed at $8.62 \%$ meanwhile the national average is illustrated as $8.60 \%$. In general it can be observed that the appreciation for one year is higher than the appreciation for 3 years, and this one is higher than the appreciation for 5 years, and this one is higher than the appreciation for 10 years. This is demonstrated by the Sample averages and national averages for 1, 3, 5, and 10 years. Even the national mean goes to a reduction of 50\% when we compared the appreciation in a year period $4.3 \%$ with $8.6 \%$ for one year.

Table 2: General Home Appreciation for the sixty largest US markets by Population

\begin{tabular}{ccccc}
\hline & 1 Year & 3 Years & 5 Years & 10 Years \\
\hline Sample Mean & 0.09 & 0.08 & 0.06 & 0.04 \\
Sample Median & 0.08 & 0.07 & 0.06 & 0.04 \\
Std Dev & 0.03 & 0.03 & 0.03 & 0.02 \\
National Mean & 0.09 & 0.07 & 0.06 & 0.04 \\
\hline
\end{tabular}

\section{MODEL PROCEDURE}

Previous studies of the effect of schools quality in the home prices have tried to establish a direct causal link between schools quality and home prices. But none of the ones consulted by the author determined if in Houston, Texas there is a direct relationship between the Home prices and the school quality. Deininger standard logarithmic price function is illustrated as linear; it is called the Hedonic Price model.

$$
\operatorname{In}(P)=\alpha_{0}+\alpha_{1} x_{i}+\alpha_{2} z+\varepsilon_{i}
$$

Where $\ln$ (Price) is the natural $\log$ of the list price for house $i, x$ is the set of observable housing characteristics such as square footage and building material, $z$ is the neighborhood. Deininger proposed a deviation of the hedonic model:

$$
\operatorname{In}(P)=\alpha_{0}+\alpha_{1} x_{i}+\alpha_{2} \text { city }+\alpha_{3} q+\varepsilon_{i}
$$

Where $\ln$ (Price) is the natural $\log$ of the list price for house $i, x$ is the set of observable housing characteristics such as square footage and building material, $\gamma$ city represent the location characteristics and $z$ various quality measures of public schools are represented by the vector $q$. Deininger concluded that in the Pitt County in North Carolina, specifically the Greenville area residents pay 2.7 percent more for houses located in school districts with proficiency scores that are ten percentage points more higher than other districts. The drawback of the Hedonic Price is that all relevant house or neighborhood characteristics cannot be observed; hence results are biased because of omitted variables.

\section{DATA AND SUMMARY STATISTICS}

Although the home prices are affected by several numerous variables on the supply side as well as on the demand side; this study focuses in the relationship between home prices and schools quality for the greater area of Houston. The school quality analysis of this study is based on the information available in the website of the Houston Association of Realtors. From this website a sample of 34 Independent School Districts were selected in order to be analyzed in conjunction with the Average Annual Price Rate of Increase Since 1997 and the Median Price Rate for 2006. From the randomly selected 34 Independent School Districts it was found that most of the schools were concentrated in the recognized accountability rating of the schools as illustrated in the Table 3.0 below. 
Table 3.0: Accountability Rating of Schools

\begin{tabular}{ccccc}
\hline Groups & Count & Sum & Sample mean & Variance \\
\hline Exemplary & 3 & 199.36185 & 66.45395 & 68.937456 \\
Recognized & 20 & 1224.198 & 61.2099 & 19.935393 \\
Acceptable & 11 & 742.3746 & 67.4886 & 283.37884 \\
\hline
\end{tabular}

The first analysis performed in the data intended to determine if the mean home price is the same for the exemplary, recognized and academic acceptable schools. For this analysis the mean of median prices for the year 2006 were utilized. The first question for this analysis is: Can we conclude using a .05 level of significance that the mean of median home prices for the year 2002 of homes located in exemplary school districts is the same as the corresponding price of homes located in recognized and acceptable school districts?

$\mathrm{m} 1=$ the mean (\$USD) of median home prices for the year 2006 of homes located in exemplary school district $\mathrm{m} 2=$ the mean (\$USD) of median home prices for the year 2006 of homes located in recognized school district $\mathrm{m} 3$ = the mean (\$USD) of median home prices for the year 2006 of homes located in academic acceptable school district.

Hypotheses:

Ho: $\mathrm{m} 1=\mathrm{m} 2=\mathrm{m} 3$

Ha: Not all of the means are equal.

Table 4.0: Table of Analysis of Variance ANOVA

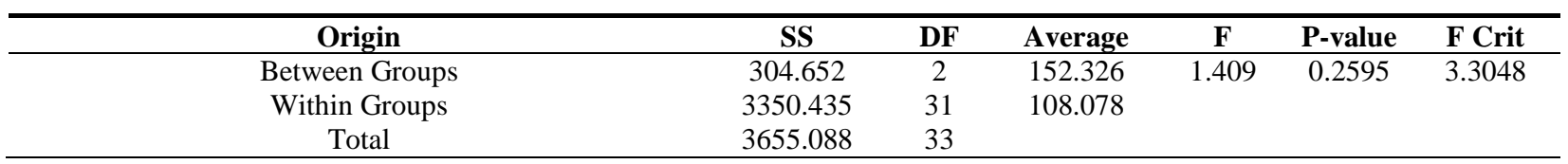

According to Table 4.0 F = $1.41<\mathrm{F}$ Critical $=3.30$ that may lead to accept the null hypothesis, furthermore it is observed that the $\mathrm{p}$ value $=0.25$ is $>$ than the level of significance of 0.05 . Therefore the null hypothesis is accepted. As a result of the above with a level of confidence of 0.05 with the analysis of variance illustrated above there is no evidence to establish that the mean of median prices of homes in 2002 are different for homes located in exemplary districts than the ones located in recognized districts or the acceptable districts.

\section{SCHOOL QUALITY EVALUATION CRITERIA}

In order to evaluate the quality of the schools four different evaluation criteria has been considered: Pass TAAS Test, College Admission Testes, SAT Mean Score and ACT Average. Every one of this evaluation criteria were correlated to the Average annual rate of price increase since 1997 in the Table 5.0. As it is illustrated in this table the average annual rate of increase have its highest correlation degree with this evaluation criteria is observed in the Pass TAAS test, and it is observed as -0.58 . Therefore no evidence has been found that the school quality evaluation criteria selected have a positive and strong correlation with the annual price rate increase. Multicollinearity has been observed between the ACT averages, the SAT Mean Score and probably with Pass TASS Test. 
Table 5.0: Correlation Coefficients Home Price Annual Rate Increase:

\begin{tabular}{|c|c|c|c|c|c|}
\hline & $\begin{array}{l}\text { Average Annual } \\
\text { Rate of Increase }\end{array}$ & $\begin{array}{c}\text { Pass TAAS } \\
\text { Test }\end{array}$ & $\begin{array}{c}\text { College } \\
\text { Admission Tested } \\
\end{array}$ & SAT Mean Score & $\begin{array}{c}\text { ACT } \\
\text { Average }\end{array}$ \\
\hline $\begin{array}{l}\text { Average Annual Rate of } \\
\text { Increase Since } 1997\end{array}$ & 1.00 & & & & \\
\hline Pass TAAS Test & -0.58 & 1.00 & & & \\
\hline College Admission Tested & -0.22 & 0.53 & 1.00 & & \\
\hline SAT Mean Score & -0.38 & 0.74 & 0.68 & 1.00 & \\
\hline ACT Average & -0.32 & 0.67 & 0.61 & 0.92 & 1.00 \\
\hline
\end{tabular}

Pass TAAS Test, College Admission Tests, SAT Mean Score and ACT Average were correlated to the Average median home price for 2002 in the Table 6.0. As illustrated in this table the median home price in 2002 have its highest correlation degree with the SAT Mean Score, and it is observed as 0.53 . Therefore in order to minimize potential multicollinearity issues the study will focus in the SAT Mean Score only.

Table 6.0: Correlation Coefficients Home Median Price

\begin{tabular}{|c|c|c|c|c|c|}
\hline & $\begin{array}{c}\text { Median Price } \\
2002\end{array}$ & $\begin{array}{c}\text { Pass TAAS } \\
\text { Test }\end{array}$ & $\begin{array}{c}\text { College } \\
\text { Admission Tested }\end{array}$ & SAT Mean Score & $\begin{array}{c}\text { ACT } \\
\text { Average }\end{array}$ \\
\hline Median 02 & 1.00 & & & & \\
\hline Pass TAAS Test & 0.39 & 1.00 & & & \\
\hline College Admission Tested & 0.39 & 0.53 & 1.00 & & \\
\hline SAT Mean Score & 0.53 & 0.74 & 0.68 & 1.00 & \\
\hline ACT Average & 0.49 & 0.67 & 0.61 & 0.92 & 1.00 \\
\hline
\end{tabular}

\section{SAT VS AVERAGE MEDIAN HOME PRICE}

When we isolate the SAT Mean Scores with the average of the median home price for the 34 randomly selected Independent School Districts and we plot the points into a scatter chart as illustrated in the Figure 2.0, we start to get the feeling of the relationship between these two variables.

Figure 2.0: Median Home Price 2006 (\$USD)

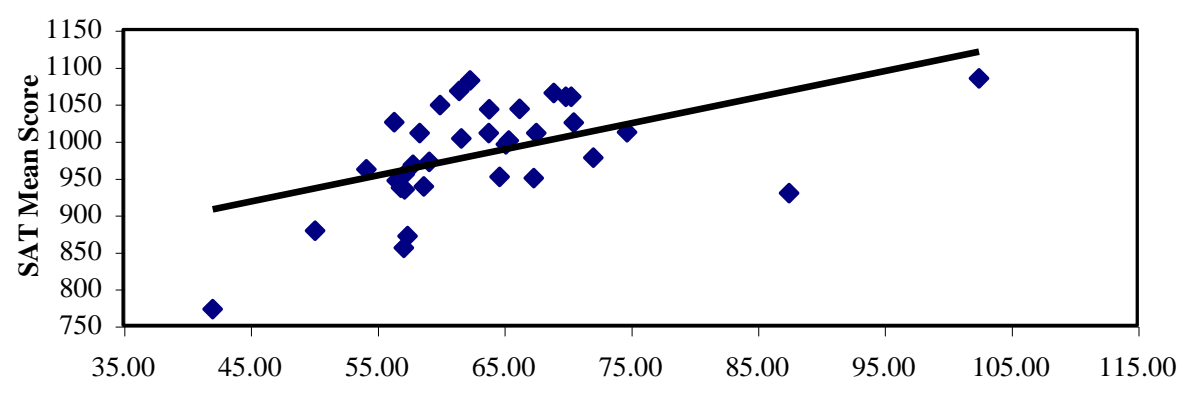

Test for significance and Hypotheses:

Ho: $\beta 1=0$

Ha: $\beta 1 \neq 0$ 
Table 7.0: ANOVA Testing for SAT vs Average Median Home Price

\begin{tabular}{cccccc}
\hline ANOVA & & & & & \\
\hline & df & SS & MS & F & Significance F \\
Regression & 1 & 1020.6010 & 1020.6010 & 12.3968 & 0.0013 \\
Residual & 32 & 2634.4873 & 82.3277 & & \\
Total & 33 & 3655.0883 & & & \\
\hline
\end{tabular}

As illustrated in Table 7.0 above the $\mathrm{F}$ test for significance is rejecting the null hypothesis as $\mathrm{F}>$ significance $\mathrm{F}$

\section{CONCLUSION}

The study found evidence that there is positive linear correlation between the SAT Mean Score and the mean median home prices. This confirms that the better the school district the higher the price of the home. The study did not find evidence that there is a positive linear correlation between the SAT Mean Score and the Average Annual Home Price Rate Increase mean median home prices. The home pricing seems to be also affected by the supply and demand relationships than for the public school district, in which the homes are located, an evidence of that was found when we listed the most expensive subdivisions or the most expensive cities and we compared this data with the school districts where these homes are located. At the very high end of the society the quality of the public education doesn't seem to affect the house pricing.

In this study, extensive sources has been consulted in order to determine the relationship that most of the real estate literature promote "the better the School District where your home is located the higher the price that you may charge for your home". The first difficulty that the study found is that the data is not available between the same categories, e.g. if the school rankings are available by School Districts the price index are available by cities. Of course in a city several school districts may reside. Even a school district could reside in two different cities.

This study observed how the home price index has been maintaining a steady growth. On one hand when the GDP trend reflects a good health of the economy it has been observed how in the US the demand for housing is pushing up the price index; on the other hand when the GDP trend indicates concerns in the health of the economy the federal reserve with the monetary policy motivate the home price index.

\section{REFERENCES}

1. 1997 Economic Census. Real State and Rental and Leasing, Geographic Area Series. US Department of Commerce, Economics and Statistics Administration. US Census Bureau.

2. Black, Sandra, The Quarterly Journal of Economics, Do better Schools Matter? Parental Valuation of Elementary, 1999.

3. Bogart, Williams T and Brian Cromwell, How Much More is a Good School District Worth? National Tax Journal, L 1997.

4. Data reported by states to U.S. Department of Education, National Center for Education Statistics, Common Core of Data, Public Elementary/Secondary Education Agency Universe Survey, 2000-01, Version 1a, and Public Elementary/Secondary School Universe Survey, 1999-2000, Version 1b.

5. Deininger, Andrew, Department of Economics East Carolina University, North Carolina, Perception of Public School Quality and It's effects on Housing Prices: Evidence from Pitt County, North Carolina, 1999

6. Department of Education, Planning, Budget and Resource Development Office, Planning and Evaluation Branch, Evaluation Section, Statewide Summary Spring 2001, School Quality Survey School Quality Survey, May 2002.

7. Downes, Thomas A and Jeffrey E Zabel, The impact of School Characteristics on House Prices: Chicago, 1987-1991, unpublished manuscript, 1997. 
8. Glink, Ilyce R., 100 Questions Every First Time Home Buyer Should Ask, second edition, New York, 2000.

9. http://www.census.gov Web page of US Department of Commerce, Economics and Statistics Administration. US Census Bureau.

10. http://www.har.com Web page of Houston Association of Realtors

11. http://www.nar.org Web page of National Association of Realtors.

12. http://www.uh.edu/irf/index.htm. Website for the University of Houston's Center for Public Policy, Institute for Regional Forecasting.

13. Office of Federal Housing Enterprise Oversight (OFHEO), financial safety and soundness regulator for Fannie Mae and Freddie Mac, release the OFHEO's House Price Index (HPI) that is a quarterly report analyzing housing appreciation trends.

14. Office of Federal Housing Enterprise Oversight House Price Index Fourth Quarter 2001 March 1, 2002.

15. Office of Federal Housing, Enterprise Oversight House Price Index, Fourth Quarter 2001, March 1, 2002.

16. TDNet, VC/UHV Library.

17. The Economist, Global House Prices, As safe as what?, Aug 29th 2002

18. The Economist, House prices Going through the roof, Mar 28th 2002

19. The Economist, Property prices, Homing in on trouble, Mar 11th 2004

20. U.S. Department of Housing and Urban Development

NOTES 
NOTES 